\title{
IMPACT OF BEETROOT (BETA VULGARIS RUBRA) AND/OR SWISS CHARD (BETA VULGARIS CICLA) JUICES ORAL ADMINISTRATION AGAINST BARIUM CHLORIDE-INDUCED HYPOKALEMIA, ATPASE DISTURBANCE HEART AND LUNG TOXICITY IN RATS
}

\author{
ALYAE M S GABAL*, GEHAN M MORSY \\ Department of Biochemistry and Nutrition, Women's College, Ain Shams University, Cairo, Egypt. Email: alyeesalah@gmail.com \\ Received: 10 May 2020, Revised and Accepted: 21 June 2020
}

\section{ABSTRACT}

Objective: The research designed to explore, for the $1^{\text {st }}$ time, the probable antioxidant activity and protective effect of oral administration of beetroot (Beta vulgaris Rubra) and Swiss chard (B. vulgaris Cicla) juices against barium chloride $\left(\mathrm{BaCl}_{2}\right.$ )-induced toxicity in rats through investigating the changes on complete blood picture, heart and lung oxidative biomarkers, cardiac function tests, inflammatory markers as well as adenosine triphosphatase (ATPase) activity, hypokalemia, and electrolyte disturbances.

Methods: Seventy-five adult male albino rats of Sprague-Dawley strains (150 $\pm 5 \mathrm{~g})$ were divided into five groups (15/each) except healthy control group which contains 10 rats, and $\mathrm{BaCl}_{2}$ control group that contains 20 rats as follows: Group I: Healthy control; Group II: $\mathrm{BaCl}_{2}$ control, and Groups III, IV, and V: $\mathrm{BaCl}_{2}$ intoxicated groups supplemented with $1 \mathrm{ml}$ of beetroot, Swiss chard, and combination of both juices, respectively $/ \mathrm{kg}$ body weight 3 times per week orally.

Results: Results explored that beetroot and Swiss chard juices contain significant amount of polyphenols and flavonoids as well as macro- and micronutrients that improved the complete blood picture, heart and lung oxidative stress parameters, cardiac function tests, inflammatory markers, ATPase activity, hypokalemia, and also electrolyte balance in supplemented groups compared to $\mathrm{BaCl}_{2}$ control group.

Conclusion: This search illustrated that fresh beetroot and Swiss chard juices can improve various biochemical abnormalities resulted from $\mathrm{BaCl}_{2}$ toxicity. $\mathrm{BaCl}_{2}$ intoxicated rats that were supplemented with combination of juices showed the most significant improvements.

Keywords: Beetroot, Swiss chard, Barium chloride, Oxidative stress, Inflammation, Heart, Lung, adenosine triphosphatase, Hypokalemia.

(c) 2020 The Authors. Published by Innovare Academic Sciences Pvt Ltd. This is an open access article under the CC BY license (http://creativecommons. org/licenses/by/4. 0/) DOI: http://dx.doi.org/10.22159/ajpcr.2020.v13i8.38232

\section{INTRODUCTION}

Chemical contamination is a major global issue of food and water safety and quality. Exposure to chemicals at toxic levels, associated with nutritional imbalances, is suspected to be involved in causing several diseases. Protection of our diet from these hazards should be considered one of the essential public health issues in all countries [1].

Barium (Ba) is an alkaline earth element that oxidized easily if exposed to air. It is present as $\mathrm{Ba}^{2+}$ ion in surface and ground water and mainly derived from rock and minerals. World widely drinking water contaminated with Ba became an important public health problem. The amount of Ba concentration in drinking water in different countries was reached $1 \mu \mathrm{g}-500 \mu \mathrm{g} / \mathrm{l}$. The daily intake of Ba from drinking water daily is $2-1200 \mu \mathrm{g}$. Ba chloride $\left(\mathrm{BaCl}_{2}\right)$ is used in pigments industry, glass and ceramics, refining aluminum, tanning leather, photographic paper, and boiler compounds for water softening [2].

Ba is found naturally in different food stuffs. Among plant products, tea and coffee represent highest concentrations ( 2.7 and $1.2 \mathrm{mg} / 100 \mathrm{~g}$ ). In cereal products, bran flakes have the highest concentration $(0.39 \mathrm{mg} / 100 \mathrm{~g})$. Unpeeled apples have the highest concentration of Bain the fruitgroup and contain about $(0.075 \mathrm{mg} / 100 \mathrm{~g})$. Eggs contain within $0.76 \mathrm{mg} / 100 \mathrm{~g}$ while meats contain $0.04 \mathrm{mg} / 100 \mathrm{mg}$ [3].

When Ba ingested, it passes rapidly through the gastrointestinal mucosa, goes into blood circulation, then distributed to soft tissues within 30 min, mainly aorta, lung, heart, brain, spleen, and kidney. The exact mechanism of Ba toxicity is a blockage of passive trans-membrane potassium $\left(\mathrm{K}^{+}\right)$conductance in excitable cells by the $\mathrm{Ba}^{2+}$ ion as well as production of reactive oxygen species (ROS) inside the body [4]. The distinctive systemic role of Ba toxicity is "violent contraction of cardiac, smooth, and striated muscle." Clinically, this action is demonstrated as skeletal muscle contraction, colic, diarrhea, salivation, and vomiting. Later, blood pressure drops and skeletal muscles exhibit paralysis. Finally, death occurs as a result of cardiac failure and arrhythmia [5].

Potassium is a very important mineral inside human body. Potassium disorders as hypokalemia is common electrolyte disorder caused by changes in potassium intake, transcellular shifts, or altered excretion. Metal toxicity, diuretic use, and gastrointestinal losses are common causes of hypokalemia. Severe, potassium disorders can lead to lifethreatening cardiac disturbances and neuromuscular dysfunction [6].

Plants play a very important role to mankind due to their medicinal as well as nutritional properties. Plants are considered cheap and ideal source of minerals including potassium as well as phytochemicals [7]. Plants also have been used as a traditional medicine in treating different diseases [8]. Beetroot (Beta vulgaris Rubra) and Swiss chard (B. vulgaris Cicla) are vegetables belong to the Chenopodiaceae family, commonly used in traditional cooking, and considered cheap source of nutrients [9].

Red beetroot (B. vulgaris Rubra) is a naturally occurring root vegetable and a rich source of bioactive and phytochemical components as betalains (e.g., betacyanins and betaxanthins), flavonoids, saponins, as well as inorganic nitrate. It also contains minerals as potassium, iron, sodium, calcium, phosphorous, magnesium, and manganese. Beetroot is a good supply of vitamins such as A, C, and B-complex. Beetroot juice supplementation as a cost-effective strategy possesses valuable roles in the improving many clinical and pathologic conditions. Moreover, 
consuming beetroot in the form of juice, pickled, pureed, boiled, jam processed, powder, bread, and oven dried across different food cultures has been increased [10].

Swiss chard (B. vulgaris Cicla) is a green leafy vegetable cultivated widely with low cost and many uses in cooked dishes. Leaves of chard are rich in vitamins as A, C, and B as well as folic acid. It considered as a good source of minerals such as potassium, calcium, phosphorus, and iron. It is used as a common traditional medicine for many diseases. Phytochemical screenings of chard leaves revealed the occurrence of fatty acids as (palmitic, stearic, oleic, linoleic, and linolenic acids), phospholipids, glycolipids, flavonoids, phenolic acids, pectin, polysaccharides, saponins, betalains, and also apigenin. Chard leaves can be used in cooking taro (alqilqas), cooked as spinach or in making salads [11].

In this research, we will explore for the $1^{\text {st }}$ time the effect of natural freshly prepared juices of beetroot and Swiss chard on $\mathrm{BaCl}_{2}$ toxic effects in rats.

\section{MATERIALS AND METHODS}

\section{Materials}

Chemicals

$\mathrm{Bacl}_{2}$ was the purest grades available Sigma-Aldrich (St. Louis, MO, USA). It was dissolved in distilled water and given to rats at a dose of $200 \mathrm{mg} / \mathrm{kg}$ body weight [12]

\section{Plants}

Beetroot and Swiss chard were purchased from local market (January 2020) and authenticated by botanist (Department of Botany, Women Faculty, Ain Shams University).

Diet

Rats were fed on standard commercial diet according to the National Research Council [13]. This diet was obtained from Egyptian Organization for Biological Products and Vaccines (Helwan, Egypt).

\section{Animals}

Seventy-five adult male albino rats of Sprague-Dawley strains weighing $(150 \pm 5 \mathrm{~g})$ were supplied by Egyptian Organization for Biological Products and Vaccines (Helwan, Egypt). All animal experimentations were carried out in conformity with the Committee for the Purpose of Control and Supervision of Experiments on Animals guidelines and were approved by the Institutional Animal Ethics Committee.

\section{Methods}

Preparation of fresh juices

One gram of beetroot or Swiss chard was mixed with $5 \mathrm{ml}$ distilled water in the electric mixer and another $5 \mathrm{ml}$ of water were used to wash any residue in the mixer then juice is filtered to give $10 \%$ juice concentration. Rats were supplemented with juices at a dose of $1 \mathrm{ml} / \mathrm{kg}$ body weight [14].

Measurement of total polyphenols, total flavonoids content, and total antioxidant activity of fresh juices samples

The amount of total polyphenols and total flavonoids content in each plant juice was determined by Folin-Ciocalteu reagent as described by Arnous et al. [15], Joyeux et al. [16], respectively. Total antioxidant activity of juices was determined by the 1,1-diphenyl-2-picrylhydrazyl method according to Brand-Williams et al. [17]. The experiments were repeated in triplicate.

\section{Determination of some nutrients content in fresh juices samples}

The samples were analyzed proximately (moisture, ash, crude protein, crude fat, and crude fiber) using method of AOAC International [18]. Carbohydrate content was determined by difference method from other constituents. Minerals ( $\mathrm{Fe}, \mathrm{Na}$, and $\mathrm{K}$ ) were determined by atomic emission spectroscopy according to AOAC International [18]

\section{Experimental design}

All rats were housed individually with constant controlled environments in stainless steel cages and fed on the balanced diet with drinking water ad libitum for 7 days for acclimatization. Animals classified randomly into five groups of 15 animals (15/each), except healthy control group which contain 10 rats and $\mathrm{BaCl}_{2}$ control group which contains 20 rats.

Rats were treated as follows: Group I: Healthy control group, rats received a placebo $1 \mathrm{ml}$ distilled water 3 times weekly by oral intubation; Group II: $\mathrm{BaCl}_{2}$ control group, rats received $200 \mathrm{mg} / \mathrm{kg} \mathrm{BaCl}_{2}$ dissolved in distilled water 3 times weekly by oral intubation; Group III: Rats received $200 \mathrm{mg} / \mathrm{kg} \mathrm{BaCl}_{2}$ and supplemented with beetroot juice 3 times weekly by oral intubation; Group IV: Rats received $200 \mathrm{mg} / \mathrm{kg} \mathrm{BaCl}_{2}$ and supplemented with Swiss chard juice 3 times weekly by oral intubation; and Group V: Rats received $200 \mathrm{mg} / \mathrm{kg} \mathrm{BaCl}_{2}$ and supplemented with beetroot and Swiss chard juices (1:1) 3 times weekly by oral intubation.

\section{Handling of blood, lung, and heart samples}

At the end of the experimental period (35 days), rats were fasted overnight, sacrificed under sodium barbiturate anesthesia. Blood sampleswere collected from the hepaticportal vein, serum wasseparated for biochemical analyses. Heart and lung samples were separated, rinsed, dried on filter paper, homogenized in Tris hydrochloride buffer $(\mathrm{pH}$ 7.4), and centrifuged. The resulting supernatants were stored at $-80^{\circ} \mathrm{C}$ immediately until doing the biochemical analysis.

\section{Biochemical analysis}

Complete blood picture (CBC) in whole blood was determined according to Dacie and Lewis [19]. Heart and lung malondialdehyde (MDA), advanced oxidation protein products (AOPP), and reduced glutathione (GSH) levels as well as catalase (CAT) activity were determined according to Draper and Hadley [20], Witko et al. [21], Beutler et al. [22], Aebi [23]. Serum creatine kinase isoenzyme-MB (CK-MB), lactate dehydrogenase (LDH), and also cardiac and lung $\mathrm{Na}^{+}-\mathrm{K}^{+}$adenosine triphosphatase (ATPase) activities were determined according to standard methods using diagnostic kits from BioSystems S.A. (Barcelona, Spain) according to Reitman and Frankel [24], Dawson et al. [25], Kawamoto et al. [26], respectively, while the assessment of serum cardiac troponin I (cTnI) level was carried out by enzyme-linked immunosorbent assay (ELISA) using kit purchased from Cloud-Clone Corp., USA, according to Apple et al. [27]. Cardiac collagen and cardiac matrix metalloproteinase-1 (MMP-1) were determined by quantitative sandwich immunoassay technique ELISA kit (Cusabio, USA) according to Neuman and Logan [28] and enzyme-linked immunosorbent assay kits (Cloud-Clone Corp., USA) according to Zhang et al. [29], respectively. Serum was analyzed for tumor necrosis factor-alpha (TNF- $\alpha$ ) level and myeloperoxidase (MPO) activity using Koma Biotech ELISA kit. Serum sodium and potassium levels were determined using the flame photometry method (410 flame photometer, Chiron Diagnostics) following the manufacturer's guidelines [30]

\section{Statistical analysis}

Results were expressed as mean \pm standard deviation of the mean. Differences among means were tested for statistical significance by one-way analysis of variance using SPSS package version 16. Statistical significance was considered when $p \leq 0.05$ according to Levesque [31].

\section{RESULTS}

Total flavonoids, total polyphenols content, and total antioxidant capacity of beetroot and Swiss chard juices

Table 1 illustrates that both beetroot and Swiss chard juices have a high content of active components such as flavonoids and polyphenols and consequently have high antioxidant capacity. On comparison between beetroot and Swiss chard juice results, it was found that beetroot juice has a higher content of these active constituents. 
Nutritional composition of $100 \mathrm{ml}$ of beetroot and Swiss chard juices

Table 2 reveals that both beetroot and Swiss chard juices are good sources of both macro- and micronutrients compared with their prices. It was found that Swiss chard juice has a higher content of moisture, ash, protein, fiber, as well as minerals as sodium, potassium, and iron when compared with beetroot juice which has a higher content of both carbohydrate and fat.

Effect of beetroot and/or Swiss chard juices on complete blood picture in $\mathrm{BaCl}_{2}$ intoxicated rats

Treatment of experimental rats with $\mathrm{Bacl}_{2}$ in (Table 3) caused a significant reduction $(\mathrm{p} \leq 0.05)$ in red blood cells (RBCs), hemoglobin $(\mathrm{Hb})$, and platelet (PLT) values and caused a significant increase in white blood cells (WBCs) count on comparison with healthy control group while supplementation with both beetroot and Swiss chard juices

Table 1: Total flavonoids, total polyphenols, and total antioxidant capacity of beetroot and Swiss chard juices

\begin{tabular}{lll}
\hline Parameter & $\begin{array}{l}\text { Beetroot } \\
\text { juice }\end{array}$ & $\begin{array}{l}\text { Swiss chard } \\
\text { juice }\end{array}$ \\
\hline $\begin{array}{l}\text { Total flavonoids (mg/1 ml fresh juice) } \\
\text { Total polyphenols (mg gallic acid }\end{array}$ & 0.58 & 0.31 \\
$\begin{array}{l}\text { equivalents/1 ml fresh juice) } \\
\text { Total antioxidant capacity (\%) }\end{array}$ & 6.8 & 1.5 \\
\hline
\end{tabular}

Table 2: Nutritional composition of $100 \mathrm{ml}$ beetroot and Swiss chard juices

\begin{tabular}{lll}
\hline Nutrient content & $\begin{array}{l}\text { Beetroot } \\
\text { value/100 } \mathbf{~ m l ~}\end{array}$ & $\begin{array}{l}\text { Swiss chard } \\
\text { value/100 } \mathbf{~ m l}\end{array}$ \\
\hline Moisture (g) & 83.4 & 89.57 \\
Ash (g) & 0.80 & 2.23 \\
Protein (g) & 0.90 & 1.88 \\
Carbohydrates (g) & 13.76 & 4.13 \\
Fat (g) & 0.12 & 0.10 \\
Total dietary fiber (g) & 1.02 & 2.09 \\
Sodium (mg) & 80.32 & 179 \\
Potassium (mg) & 314.17 & 548.57 \\
Iron (mg) & 0.93 & 2.26 \\
\hline
\end{tabular}

caused a significant improvements $(p \leq 0.05)$ in all parameters and the most improvements were found in the group that supplemented with both juices.

Impact of beetroot and/or Swiss chard juices supplementation on heart oxidative status in $\mathrm{BaCl}_{2}$ treated rats

In Table 4 , there were a significant increase $(\mathrm{p} \leq 0.05)$ in oxidative stress parameters and, on the other hand, a significant decrease in antioxidant parameters in the heart of $\mathrm{BaCl}_{2}$ control group as compared to healthy control group. While Barium intoxicated rats supplemented with beetroot and swiss chard juices showed significant improvement in heart antioxidant status $(\mathrm{p} \leq 0.05)$ in comparison with Barium chloride control group.

Effect of beetroot and/or Swiss chard juices on lung oxidative status in $\mathrm{BaCl}_{2}$ intoxicated rats

Table 5 shows a significant elevation $(\mathrm{p} \leq 0.05)$ of oxidative stress parameters resulting in accumulation of MDA and AOPP in lung tissues and suppressed antioxidant power of the lung that was represented in significant decrease $(\mathrm{p} \leq 0.05)$ in CAT activity and GSH level in Barium chloride control group. While, on the other hand, Barium intoxicated rats supplemented with beetroot and swiss chard juices acquired a strong antioxidant capacity that reduced the bad effect of $\mathrm{Bacl}_{2}$ on the lung oxidative status.

Effect of beetroot and/or Swiss chard juices supplementation on cardiac enzyme activities in $\mathrm{BaCl}_{2}$ intoxicated rats

Significant alterations (Table 6) in serum LDH, CK-MB, and cTnI activities were seen in rats treated with $\mathrm{Bacl}_{2}$ as compared to control group indicating tissue degeneration. Administration of fresh juices to rats treated with $\mathrm{BaCl}_{2}$ showed significant $(\mathrm{p} \leq 0.05)$ reduction in serum activities when compared to $\mathrm{Bacl}_{2}$ treated group indicating tissue improvement.

Impact of beet root and/or Swiss chard juices on serum TNF- $\alpha$ level and MPO activity, heart collagen, and MMP-1 levels, in $\mathrm{BaCl}_{2}$ intoxicated rats

Treatment of rats with $\mathrm{Bacl}_{2}$ led to marked $(\mathrm{p} \leq 0.05)$ elevation in serum TNF- $\alpha$ level and MPO activity and also cardiac collagen and MMP-1 levels (Table 7) indicating inflammatory response and cardiac injury. Moreover, beetroot and/or Swiss chard juices supplementation to rats treated with $\mathrm{BaCl}_{2}$ showed significant $(\mathrm{p} \leq 0.05)$ decrease of TNF- $\alpha$ level, MPO activity, cardiac collagen, and MMP-1levels compared to the $\mathrm{BaCl}_{2}$ treated group.

Table 3: Effect of beetroot and/or Swiss chard juices on complete blood picture in $\mathrm{BaCl}_{2}$ intoxicated rats

\begin{tabular}{|c|c|c|c|c|}
\hline \multirow[t]{2}{*}{ Group } & \multicolumn{4}{|l|}{ Parameter } \\
\hline & $\operatorname{RBCs}\left(10^{6} / \mu \mathrm{l}\right)$ & $\mathrm{Hb}(\mathrm{g} / \mathrm{dl})$ & WBCs $\left(10^{3} / \mu \mathrm{l}\right)$ & $\operatorname{PLT}\left(10^{3} / \mu \mathrm{l}\right)$ \\
\hline Healthy control group & $9.30 \pm 0.50^{\mathrm{a}}$ & $14.22 \pm 0.77^{\mathrm{a}}$ & $7.92 \pm 0.052^{\mathrm{e}}$ & $963.73 \pm 3.02^{\mathrm{a}}$ \\
\hline Ba intoxicated rats supplemented with beetroot juice & $4.63 \pm 0.10^{\mathrm{d}}$ & $9.35 \pm 0.40^{\mathrm{d}}$ & $11.47 \pm 0.75^{c}$ & $696.03 \pm 2.79^{d}$ \\
\hline Ba intoxicated rats supplemented with Swiss chard juice & $5.92 \pm 0.36^{c}$ & $11.94 \pm 0.65^{c}$ & $13.17 \pm 0.30^{\mathrm{b}}$ & $832.82 \pm 2.08^{c}$ \\
\hline Ba intoxicated rats supplemented with beetroot and Swiss chard juices & $7.27 \pm 0.42^{\mathrm{b}}$ & $13.12 \pm 0.13^{\mathrm{b}}$ & $9.25 \pm 0.092^{\mathrm{d}}$ & $900.63 \pm 1.09^{b}$ \\
\hline
\end{tabular}

Values are expressed as means \pm SD, $n=10$. There was no significant difference between means that have the same alphabetical superscripts letter in the same column

$(\mathrm{p} \leq 0.05)$. $\mathrm{BaCl}_{2}$ : Barium chloride, SD: Standard deviation, RBCs: Red blood cells, Hb: Hemoglobin, PLT: Platelet, WBCs: White blood cells

Table 4: Impact of beetroot and/or Swiss chard juices supplementation on heart oxidative status in $\mathrm{BaCl}_{2}$ treated rats

\begin{tabular}{|c|c|c|c|c|}
\hline \multirow[t]{2}{*}{ Group } & \multicolumn{4}{|l|}{ Parameter } \\
\hline & MDA ( $\mu \mathrm{mol} / \mathrm{g})$ & AOPP (nmol /mg) & GSH (mg/g) & CAT (U/g) \\
\hline Healthy control group & $7.89 \pm 0.04^{\mathrm{e}}$ & $2.59 \pm 0.26^{\mathrm{e}}$ & $6.32 \pm 0.86^{\mathrm{a}}$ & $30.34 \pm 0.36^{\mathrm{a}}$ \\
\hline $\mathrm{BaCl}_{2}$ control group & $16.51 \pm 1.2^{\mathrm{a}}$ & $6.89 \pm 0.83^{\mathrm{a}}$ & $2.82 \pm 0.06^{\mathrm{e}}$ & $19.96 \pm 0.16^{\mathrm{e}}$ \\
\hline Ba intoxicated rats supplemented with beetroot juice & $10.59 \pm 0.41^{\mathrm{c}}$ & $4.15 \pm 0.41^{c}$ & $4.58 \pm 0.43^{c}$ & $26.27 \pm 0.98^{c}$ \\
\hline Ba intoxicated rats supplemented with Swiss chard juice & $12.83 \pm 0.56^{\mathrm{b}}$ & $5.33 \pm 0.15^{b}$ & $3.90 \pm 0.20^{\mathrm{d}}$ & $23.51 \pm 0.40^{\mathrm{d}}$ \\
\hline Ba intoxicated rats supplemented with beetroot and Swiss chard juices & $8.61 \pm 0.73^{d}$ & $3.43 \pm 0.57^{\mathrm{d}}$ & $5.44 \pm 0.19^{b}$ & $28.14 \pm 0.56^{b}$ \\
\hline
\end{tabular}

Values are expressed as means $\pm S$. D, $n=10$. There was no significant difference between means that have the same alphabetical superscripts letter in the same column $(\mathrm{p} \leq 0.05) . \mathrm{BaCl}_{2}$ : Barium chloride, MDA: Malondialdehyde, AOPP: Advanced oxidation protein product, GSH: Glutathione, CAT: Catalase 
Effect of beetroot and/or Swiss chard juices on heart and lung $\mathrm{Na}^{+}-\mathrm{K}^{+}$ATPase activity and serum $\mathrm{Na}^{+}$and $\mathrm{K}^{+}$levels in $\mathrm{BaCl}_{2}$ intoxicated rats

Results tabulated in Table $8, \mathrm{Bacl}_{2}$ treated rats showed a significant disturbance $(\mathrm{p} \leq 0.05)$ in electrolyte balance appeared by the decrement of both heart and lung $\mathrm{Na}^{+}-\mathrm{K}^{+}$ATPase activity and serum $\mathrm{K}^{+}$level associated with a significant increase in serum $\mathrm{Na}^{+}$level. Fresh juices contain significant amount of antioxidants and potassium that improved the electrolyte balance in $\mathrm{Bacl}_{2}$ treated groups.

\section{DISCUSSION}

$\mathrm{Ba}$ is a mineral that known to be environmental pollutants cause harmful effects on human health. The current study aims to examine the probable ability of beetroot and/or Swiss chard juices, used as nutritional supplements, to reveal toxic effects caused by $\mathrm{BaCl}_{2}$ in heart and lung of adult rats as they contain significant amounts of active components such as flavonoids and polyphenols as well as macro- and micronutrients that may compete with Ba toxic effects.

The results of the analysis of fresh juices samples revealed that beetroot and chard leaves may provide a natural source of antioxidants and electrolytes, especially potassium that is important for general health and can help in defending against toxic heavy metals like Ba. These results agreed with Zein [9], Zein et al. [10], Ninfali and Angelino [32], Ninfali and Antonini [33] who stated that beetroot and chard leaves and leave juices are of high biological value and contain antioxidants

Table 5: Effect of beetroot and/or Swiss chard juices on lung oxidative status in $\mathrm{BaCl}_{2}$ intoxicated rats

\begin{tabular}{|c|c|c|c|c|}
\hline \multirow[t]{2}{*}{ Group } & \multicolumn{4}{|l|}{ Parameter } \\
\hline & MDA $(\mu \mathrm{mol} / \mathrm{g})$ & AOPP (nmol/mg) & GSH (mg/g) & CAT (U/g) \\
\hline Healthy control group & $1.29 \pm 0.03^{\mathrm{e}}$ & $0.96 \pm 0.015^{\mathrm{e}}$ & $3.65 \pm 0.49^{a}$ & $88.91 \pm 1.5^{\mathrm{a}}$ \\
\hline Ba intoxicated rats supplemented with beetroot juice & $5.63 \pm 0.17^{c}$ & $2.05 \pm 0.31^{c}$ & $1.86 \pm 0.03^{c}$ & $68.77 \pm 0.45^{c}$ \\
\hline Ba intoxicated rats supplemented with Swiss chard juice & $7.12 \pm 0.25^{b}$ & $2.85 \pm 0.04^{\mathrm{b}}$ & $1.36 \pm 0.04^{\mathrm{d}}$ & $59.83 \pm 0.64^{\mathrm{d}}$ \\
\hline Ba intoxicated rats supplemented with beetroot and Swiss chard juices & $3.91 \pm 0.09^{d}$ & $1.35 \pm 0.26^{\mathrm{d}}$ & $2.9 \pm 0.21^{\mathrm{b}}$ & $77.10 \pm 0.18^{\mathrm{b}}$ \\
\hline
\end{tabular}

Values are expressed as means \pm S. D, n=10. There was no significant difference between means that have the same alphabetical superscripts letter in the same column

( $\mathrm{p} \leq 0.05) . \mathrm{BaCl}_{2}$ : Barium chloride, MDA: Malondialdehyde, AOPP: Advanced oxidation protein product, GSH: Glutathione, CAT: Catalase

Table 6: Effect of beetroot and/or Swiss chard juices supplementation on cardiac enzyme activities in $\mathrm{BaCl}_{2}$ intoxicated rats

\begin{tabular}{|c|c|c|c|}
\hline \multirow[t]{2}{*}{ Group } & \multicolumn{3}{|l|}{ Parameter } \\
\hline & LDH (U/L) & CK-MB (U/L) & cTnI $(\mathrm{Pg} / \mathrm{ml})$ \\
\hline Healthy control group & $1872 \pm 2.03^{\mathrm{e}}$ & $1166 \pm 7.31^{\mathrm{e}}$ & $400.76 \pm 1.49^{\mathrm{e}}$ \\
\hline Ba intoxicated rats supplemented with beetroot juice & $3083 \pm 1.10^{c}$ & $1802 \pm 6.44^{c}$ & $736.02 \pm 0.82^{\mathrm{c}}$ \\
\hline Ba intoxicated rats supplemented with Swiss chard juice & $3642 \pm 4.25^{b}$ & $2031 \pm 2.0915^{b}$ & $812.49 \pm 3.22^{\mathrm{b}}$ \\
\hline Ba intoxicated rats supplemented with beetroot and Swiss chard juices & $2650 \pm 0.79^{d}$ & $1684 \pm 3.07^{\mathrm{d}}$ & $619.31 \pm 0.96^{d}$ \\
\hline
\end{tabular}

Values are expressed as means \pm S. D, $n=10$. There was no significant difference between means that have the same alphabetical superscripts letter in the same column $(\mathrm{p} \leq 0.05) . \mathrm{BaCl}_{2}$ : Barium chloride, CK-MB: Creatine kinase isoenzyme-MB, LDH: Lactate dehydrogenase, cTnI: Cardiac troponin I

Table 7: Impact of beetroot and/or Swiss chard juices on heart collagen and MMP-1 levels, serum TNF- $\alpha$ level, and MPO activity in BaCl ${ }_{2}$ intoxicated rats

\begin{tabular}{|c|c|c|c|c|}
\hline \multirow[t]{2}{*}{ Group } & \multicolumn{4}{|l|}{ Parameter } \\
\hline & $\begin{array}{l}\text { TNF- } \alpha \\
(\mathrm{pg} / \mathrm{ml})\end{array}$ & $\begin{array}{l}\text { MPO } \\
\text { (ng/ml) }\end{array}$ & $\begin{array}{l}\text { Collagen } \\
\text { (pg/100 mg) }\end{array}$ & MMP-1 (ng/100 mg) \\
\hline $\mathrm{BaCl}_{2}$ control group & $83.71 \pm 0.93^{\mathrm{a}}$ & $11.57 \pm 0.88^{\mathrm{a}}$ & $984.17 \pm 0.99^{\mathrm{a}}$ & $5.84 \pm 0.45^{\mathrm{a}}$ \\
\hline Ba intoxicated rats supplemented with beetroot juice & $60.97 \pm 0.13^{c}$ & $6.17 \pm 0.25^{c}$ & $466.15 \pm 2.26^{c}$ & $3.22 \pm 0.36^{c}$ \\
\hline Ba intoxicated rats supplemented with Swiss chard juice & $70.83 \pm 0.74^{\mathrm{b}}$ & $9.57 \pm 0.41^{\mathrm{b}}$ & $642.85 \pm 2.89^{b}$ & $4.70 \pm 0.14^{\mathrm{b}}$ \\
\hline Ba intoxicated rats supplemented with beetroot and Swiss chard juices & $44.68 \pm 0.47^{\mathrm{d}}$ & $4.80 \pm 0.19^{\mathrm{d}}$ & $372.42 \pm 1.38^{\mathrm{d}}$ & $2.66 \pm 0.08^{\mathrm{d}}$ \\
\hline
\end{tabular}

Values are expressed as means \pm S. D, $n=10$. There was no significant difference between means that have the same alphabetical superscripts letter in the same column $(\mathrm{p} \leq 0.05) . \mathrm{BaCl}_{2}$ : Barium chloride

Table 8: Effect of beetroot and/or Swiss chard juices on heart and lung $\mathrm{Na}^{+}-\mathrm{K}^{+}$ATPase activity and serum $\mathrm{Na}^{+}$and $\mathrm{K}^{+}$levels in $\mathrm{BaCl}_{2}$ intoxicated rats

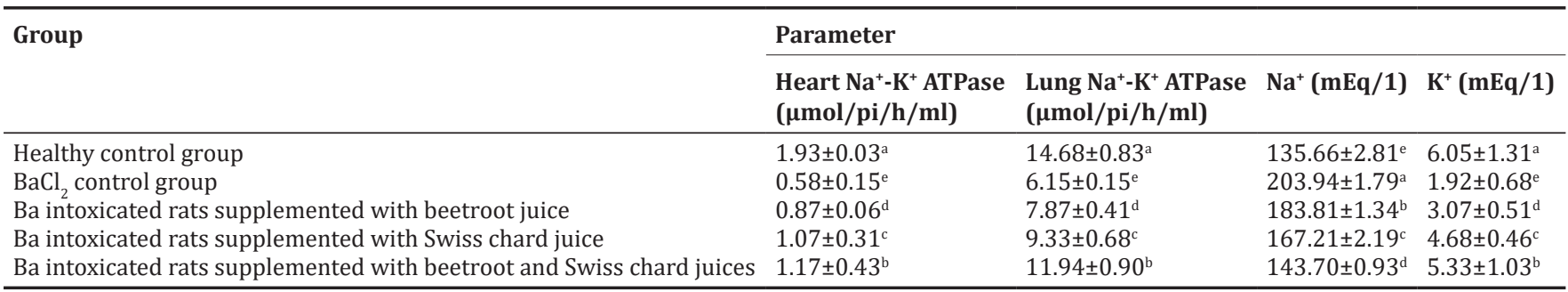

Values are expressed as means \pm S. D, $n=10$. There was no significant difference between means that have the same alphabetical superscripts letter in the same column ( $\mathrm{p} \leq 0.05) . \mathrm{BaCl}_{2}$ : Barium chloride, ATP: Adenosine triphosphatase 
that can compete oxidative stress and inflammation related to different diseases.

Under natural conditions, internal enzymatic and non-enzymatic antioxidants eliminate ROS, protecting cells against ROS. Oxidative stress resulted from the unbalance between free radicals generation and antioxidants defense causing permanent cell damage [34]. Erythrocytes are highly affected by the peroxidation process [35], their membranes exposed to covalent damage, including cross-linking and aggregation induced by ROS such as superoxides resulting from $\mathrm{Hb}$ auto-oxidation

In this current search, an abnormality was observed in different blood cell parameters in $\mathrm{BaCl}_{2}$-toxicated rats. A noticeable decrement in RBCs count, $\mathrm{Hb}$ level, and PLT count was detected in the Ba intoxicated group which resulted from DNA strand breakage in these cells due to oxidative stress associated with $\mathrm{BaCl}_{2}$ administration. Moreover, in our research, Ba administration elevated the total WBCs count, which could be due to the compensatory increment in the production of blood cellular components by the bone marrow or due to inflammatory response, according to Rawat et al. [36]. Supplementation with beetroot and/ or Swiss chard juices improved these result as a consequence of their content of antioxidants that control oxidative stress and inflammatory processes as well as the presence of essential components for newer cell generation such as protein, carbohydrate, and iron $[37,38]$.

Metals may stimulate ROS generation including hydroxyl radical, superoxide anion, and hydrogen peroxide. When ROS generated at high concentrations, oxidative stress occurs resulting in damage to lipids, proteins, and DNA, leading to cellular dysfunction [39]. This study revealed that Ba intoxication amplified the levels of both MDA and AOPP in the heart and lung tissues, causing their impairment. MDA is the breakdown product generating from the main chain reactions, leading to polyunsaturated fatty acids oxidation. MDA considered as a dependable parameter of oxidative stress-mediated lipoprotein oxidation in heart and lung tissues. Furthermore, the increased levels of AOPP marker reflected an excess of free radical generation and protein oxidative damages, shown in Ba intoxicated heart and lung tissues as well. The increment of AOPP was probably associated with free radicalmediated protein and membrane damages.

On the other hand, antioxidant defense system prevents lipid peroxidation in mammalian cells through ROS disruption. Enzymatic and non-enzymatic compounds act to eliminate and scavenge ROS. Results of this study revealed a variation in the antioxidant defense system homeostasis, displayed as a reduction in CAT and GSH levels. Ideal level of GSH is very important factor in maintenance of the structures and functions of membranes. In addition, results displayed that $\mathrm{Ba}$ administration stimulates the production of ROS that disturb heart and lung functions. The diminishing of the enzymatic and non-enzymatic antioxidant defense system was considered a main event following $\mathrm{BaCl}_{2}$-induced cardiac and lung toxicity. The study results agreed with Elwej et al. [40], Elwej et al. [41], Elwej et al. [42]. Supplementation of beetroot and Swiss chard juices improved these results while coadministration of both beetroot and Swiss chard juices to Ba-treated rats was more effective than beetroot juice or Swiss chard juice used separately against oxidative stress. Their synergistic properties were approved in the current work by elevating levels of non-enzymatic antioxidants, lowering lipid peroxidation, scavenging free radicals, and sustaining CAT activity and GSH levels.

Five weeks of $\mathrm{BaCl} 2$ oral administration induced an increase in the serum activities of CK-MB and LDH as well as the level of cTnI due to their leakage from damaged myocytes as a consequence of peroxidation and degeneration of heart tissues [43]. ROS generation is the main promoter of cellular dysfunction that increases serum biomarkers which are sensitive indicators of cardiac injury in cardiovascular diseases [44]. Serum CK-MB activity is measured as a sensitive index at an early stage of myocardial ischemia, while higher levels of LDH are relative to the degree of damage to myocardial tissues [45]. cTn ( T, I, and C) are considered to be standard blood biomarkers with high sensitivity and specificity for myocardial degeneration [46]. These contractile proteins usually released from myocardium proportional to the degree of tissue injury and myocyte membranes distribution [47]. As a consequence of cardiac membrane damage, cTnI is leaked as a result of rapid myofibrillar breakdown or may reflect the presence of free cTnI within the sarcoplasm $[48,49]$. Beetroot and Swiss chard juices prohibited the leakage of $\mathrm{LDH}, \mathrm{CK}$, and cTnI from the heart into extracellular environment. This may due to their strong antioxidant power confirming stability of membrane and lowering cardiac tissue damage.

McCauley and Washington [50] have explained that the concentration of $\mathrm{Ba}$ in the heart was 3 times more than other tissues or blood following oral dose of $\mathrm{BaCl}_{2}$, causing $\mathrm{Ba}$ accumulation in the heart. Due to the high amount of ROS generated from Ba intoxication, cardiac structure integrity was badly affected. This was cleared from the increased level of cardiac collagen associated with increased activity of MMP-1 in the $\mathrm{Ba}$ intoxicated rats. Collagen is the main extracellular matrix (ECM) protein in the heart and represents a vital goal for anti-remodeling and cardioprotective treatment. The quantity and quality of collagen was controlled under numerous physiological and pathologic circumstances. Extreme collagen deposition, leading to cardiac fibrosis, is a main factor of cardiac dysfunction and arrhythmogenicity related to death. ROS affected collagen metabolism in cardiac fibroblasts by influencing the activity of both synthesizing and degradative enzymes. ROS decreased collagenase-sensitive $[3 \mathrm{H}]$ proline incorporation as well as the presence of mRNA for procollagenase $\alpha 1(\mathrm{I}), \alpha 2(\mathrm{I})$, and $\alpha 1$ (III). ROS generation and inflammation also increased the total activity of extracellular MMP1 through the transcriptional and posttranscriptional levels. MMP-1 is a proteolytic enzyme that are regulated by inflammatory signals to mediate changes in ECM $[51,52]$. Heavy metals toxicity induced cardiac ECM expansion and remodeling as a result of the increased fibroblasts activity leading to fibrosis. Furthermore, fibroblasts produce a number of cytokines, peptides, and enzymes among which MMP and their inhibitors directly impact of ECM turnover and homeostasis. On the other hand, these alterations were arrested in the beetroot and Swiss chard juices treated rats [53].

The TNF- $\alpha$ is one of the inflammatory cytokines, that is, increased following Ba-induced ROS. Oxidative stress activates p-38 mitogen which activates protein kinase and nuclear factor kappa $\beta$ and thus plays a part in the sequence of signaling events involved in the production of myocardial TNF- $\alpha$ [54]. As a result of oxidative and inflammatory process induced by Ba toxicity, the activity of MPO increased. MPO is found mainly in the azurophilic granules of neutrophils, MPO activity measurement is used as indicator for neutrophil infiltration (inflammation) and cardiac damage in different experimental studies [55]. Moreover, excessive formation of MPO causes oxidative damage [56]. The elevation in MPO levels in Ba intoxicated rats was due to increase in the infiltration of the cardiac tissue with inflammatory cells and as a result leads to myocardial damage. However, the results of the rats supplemented with beetroot and Swiss chard juices showed marked decrease in the level of TNF- $\alpha$ and MPO activity as a consequence of the presence of anti-inflammatory flavonoids and polyphenols.

Reyes et al. [57] reported that $\mathrm{Na}^{+}-\mathrm{K}^{+}$ATPase is a membrane bound enzyme responsible for the maintenance of $\mathrm{Na}^{+}$and $\mathrm{K}^{+}$gradients over cell membranes. It is inhibited by ROS in soft tissues. Free radicals generation as a result of $\mathrm{BaCl}_{2}$ leads to oxidative stress that motivated functional changes such as ATP depletion. The study showed that the significant inhibition in the activity of both heart and lung $\mathrm{Na}^{+}-\mathrm{K}^{+}$ ATPase was due to membrane depolarization causing hypokalemia associated with hypernatremia as $\mathrm{Na}^{+}-\mathrm{K}^{+}$ATPase acted to maintain the ionic gradient for cardiac and lung cells excitability. Moreover, $\mathrm{Na}^{+}-\mathrm{K}^{+}$ ATPase activity depletion might be due to the decreased level of its substrate (ATP) and the elevation of membrane lipid peroxidation alters membranes by free radicals. On the other hand, beetroot and 
Swiss chard juices supplementation to intoxicated rats corrected the electrolyte balance and improved $\mathrm{Na}^{+}-\mathrm{K}^{+}$ATPase activity due to their antioxidant power as well as nutritive value.

\section{CONCLUSION}

Beetroot and Swiss chard are super foods that contain significant amount of macro- and micronutrients as well as active components as polyphenols and flavonoids which increase their antioxidant power. Both plant juices showed a significant improvement and ability to compete against toxicity with metals as Ba. Moreover, the synergistic effect of supplementation with both juices together was more powerful in competing toxicity when compared with each one alone. This approves that combination of different colorful foods in our diet could improve our health and protect our bodies.

\section{AUTHORS' CONTRIBUTIONS}

Dr. Alyae M. S. Gabal and Dr. Gehan M. Morsy designed the study, making of protocol, managed the work done, performed the literature searches, and completed the manuscript writing.

\section{CONFLICTS OF INTEREST}

We declare that we have no conflicts of interest.

\section{AUTHORS' FUNDING}

The authors funded the research

\section{REFERENCES}

1. Thompson LA, Darwish WS. Environmental chemical contaminants in food: Review of a global problem. J Toxicol 2019;6:1-14.

2. McNeilla IR, Isoardia KZ. Barium poisoning: An uncommon cause of severe hypokalemia. Toxicol Commun 2019;3 Suppl 1:88-90.

3. World Health Organization. Barium in Drinking-water. Background Document for Development of WHO Guidelines for Drinking-water Quality. Geneva: World Health Organization; 2004.

4. Bhoelan BH, Stevering CH, van der Boog AT. Barium toxicity and the role of the potassium inward rectifier current. Clin Toxicol 2014;52:584-93.

5. Ghasi S. Piperazine protects the rat heart against sudden cardiac death from barium chloride-induced ventricular fibrillation. Am J Ther 2008;15 Suppl 2:119-25.

6. Viera AJ. Potassium disorders: Hypokalemia and hyperkalemia. Am Fam Phys 2015;92 Suppl 6:489-95.

7. Sebastian MR, George AM. Evaluation of tocolytic activity of aqueous seed extract of Syzygium cumini on oxytocin induced preterm labor. Asian J Pharm Clin Res 2020;13 Suppl 5:162-70.

8. Sharma KR, Rana K. Biological activities of some selected Nepalese medicinal plants and isolation of chemical constituents from Callicarpa macrophylla. Int J Curr Pharm Res 2020;12:91-8.

9. Zein H, Hashish AS, Ismaiel GH. The antioxidant and anticancer activities of Swiss chard and red beetroot leaves .Curr Sci Int 2015;4Suppl 4:491-8.

10. Mirmiran P, Houshialsadat Z, Gaeini Z, Bahadoran Z, Azizi F. Functional properties of beetroot (Beta vulgaris) in management of cardio-metabolic diseases. Nutr Metab J 2020;17:3-18.

11. Reif C, Arrigoni E, Scharer H, Nystrom L, Hurrell RF. Carotenoid database of commonly eaten Swiss vegetables and their estimated contribution to carotenoid intake. J Food Compos Anal 2013;29:64-72.

12. Borzelleca JF, Condie LW, Egle JL. Short-term toxicity (one- and tenday gavage) of barium chloride in male and female rats. J Am COL. Toxicol 1998;7 Suppl 5:675-85.

13. National Research Council. Nutrient Requirements of Laboratory Animals $4^{\text {th }}$ ed. Washington, DC: National Academy Press; 1995.

14. Udonkang MI, Inyang IJ, Ukorebi AN, Effiong F, Akpan U, Bassey IE. Spectrophotometry, physiochemical properties, and histological staining potential of aqueous and ethanol extracts of beetroot on various tissues of an albino rat. Biomed Hub 2018;3:492-502

15. Arnous A, Makrisand DP, Kefalas P. Effect of principal polyphenol components in relation to antioxidant characteristics of aged red wines. J Agric Food Chem 2001:49:5736.

16. Joyeux M, Lobestein A, Anton R, Morier F. Comparative anti lipoperoxidant, anti-necrotic and scavenging potencies of terpenes and bio-flavones from gingko and some flavonoids. Planta Med
$1995 ; 61: 126-9$

17. Brand-Williams W, Cuvelier ME, Berset C. Use of a free radical method to evaluate antioxidant activity. J Food Sci and Technol 1995;28:25

18. AOAC International. Official methods of analysis. In: Horwitz W, editor. Association of Official Analytical Chemists. $19^{\text {th }}$ ed. Washington, DC, USA: AOAC International; 2012.

19. Dacie JV, Lewis SM. Practical Hematology. $6^{\text {th }}$ ed. London, UK: ELBS and Churchill Livingstone; 1984.

20. Draper HH, Hadley M. Malondialdehyde determination as index of lipid peroxidation. Methods Enzymol 1990;186:421-31.

21. Witko V, Nguyen AT, Descamps-Latscha B. Microtiter plate assay for phagocyte-derived taurinechloramines. J Clin Lab Anal 1992;6:47-53.

22. Beutler E, Duroun O, Kelly BM. Improved method for the determination of blood glutathione. J Lab Clin Med 1963;61:882-8.

23. Aebi H. Catalase in vitro. Methods Enzymol 1984;105:121-6.

24. Reitman S, Frankel S. A colorimetric method for the determination of serum glutamic oxaloacetic and glutamic pyruvic transaminases. Am J Clin Pathol 1957;28:56-63.

25. Dawson DM, Eppenberger HM, Kaplan NO. Creatine kinase: Evidence for a dimeric structure. Biochem Biophys Res Commun 1965;21 Suppl 4:346-53.

26. Kawamoto EM, Munhoz CD, Glezer I. Oxidative state in platelets and erythrocytes in aging and Alzheimer's disease. Neurobiol Aging 2005;26:857-64

27. Apple FS, Ler R, Murakami MA. Determination of 19 cardiac troponin $\mathrm{I}$ and $\mathrm{T}$ assay 99th percentile values from a common presumably healthy population. Clin Chem 2012;58 Suppl 11:1574-81.

28. Neuman RE, Logan MA. The determination of collagen and elastin in tissues. J Biol Chem 1950;186:549-56.

29. Zhang J, Fujimoto N, Iwata K, Iwata H, Sakai T, Okada Y. A one-step sandwich enzyme immunoassay for human matrix metalloproteinase 1 (interstitial collagenase) using monoclonal antibodies. Clin Chim Acta 1993;219:114.

30. Akhigbe RE, Ige SF, Afolabi AO, Oyeyipo PI, Ajao FO, Ajayi FA. Water balance and serum levels of some electrolytes in oral contraceptivetreated female Wistar rats. J Med Sci 2008;8:591-4.

31. Levesque R. SPSS Programming and Data Management: A Guide for SPSS and SAS Users. $4^{\text {th }}$ ed. Chicago, IL: SPSS Inc.; 2007.

32. Ninfali P, Angelino D. Nutritional and functional potential of Beta vulgaris Cicla and Rubra. Fitoterapia 2013;89:188-99.

33. Ninfali P, Antonini E. Great nutraceutical potential of bioactive compounds from Beta vulgaris Cicla and Rubra. J Nutrafoods 2018;17:75-81

34. Chipman JK, Parsons JL, Beddowes EJ. The multiple influences of glutathione on bromate genotoxicity: Implications for the dose response relationship. Toxicology 2006;221:187-9.

35. Ghorbel I, Maktouf S, Kallel C, Chaabouni SE, Boudawara T, Zeghal N. Disruption of erythrocyte antioxidant defense system, hematological parameters, induction of pro-inflammatory cytokines and DNA damage in liver of co-exposed rats to aluminium and acrylamide. Chem Biol Interact 2015;236:31-40.

36. Rawat SK, Singh RK, Bansode FW, Singh P, Singh RP. Nitrate induced toxicity on some haematological parameters of Charles Foster rats. J Recent Adv Appl Sci 2013;28:35-8

37. Trifunović S, Topalović A, Knezević M, Vajas V. Free radicals and antioxidants: Antioxidative and other properties of Swiss chard (Beta vulgaris L. subsp. cicla). Agric For 2015;61:73-92.

38. Neha P, Jain SK, Jain NK, Jain HK, Mittal HK. Chemical and functional properties of beetroot (Beta vulgaris L.) for product development: A review. Inter J Chem Stud 2018;6 Suppl 3:3190-4

39. Umarani V, Muvvala S, Ramesh A. Rutinpotentially attenuates fluorideinduced oxidative stress-mediated cardiotoxicity, blood toxicity and dyslipidemia in rats. Toxicol Mech Methods 2015;25:143-9.

40. Elwej A, Ben Salah G, Kallel C, Fakhfakh F, Zeghal N, Ben Amara I. Protective effects of pomegranate peel against hematotoxicity, chromosomal aberrations, and genotoxicity induced by barium chloride in adult rats. Pharm Biol 2016;54 Suppl 6:964-74

41. Elwej A, Ghorbel I, Chaabane M, Soudani N, Marrekchi R, Jamoussi K, et al. Protective effects of dietary selenium and Vitamin $\mathrm{C}$ in bariuminduced cardiotoxicity. Hum Exper Toxicol 2017a;36 Suppl 11:1146-57.

42. Elwej A, Ghorbel I, Chaabane M, Soudani N. Zinc and selenium modulate barium-induced oxidative stress, cellular injury and membrane-bound ATPase in the cerebellum of adult rats and their offspring during late pregnancy and early postnatal periods. Arch Physiol Biochem 2017b;124 Suppl 5:1-10.

43. Zhou R, Zheing P, Van L, Zheng J, Dia G. Cardioprotective effect of fluvastatin on isoproterenol-induced myocardial infraction in rat. Eur J 
Pharmacol 2008;586:244-50.

44. El Berry AA, Abdel-Naim AB, Abdel-Sattar EA, Nagy AA, Mosli HA, Mohamadin AM. Cranberry (Vaccinium macrocarpon) protects against doxouruicin-induced cardiotoxicity in rats. Food Chem Toxicol 2010;48:1178-84.

45. Hansi DP, Stanely P, Mainzen P. Cardioprotective effect of gallic acid on cardiac troponin-T, cardiac marker enzymes, lipid peroxidation products and antioxidants in experimentally induced myocardial infraction in Wistar rats. Chem. Biol Interact 2009;179:118-24.

46. Antman EM. Decision making with cardiac troponin tests. N Engl J Med 2002;346:2079-82.

47. Remppis A, Scheffold T, Greten J. Intracellular compartmentation of troponin T: Release kinetics after global ischemia and calcium paradox in the isolated perfused rat heart. J Mol Cell Cardiol 1995;27:793-803.

48. O'Berien PJ, Smith DE, Knechtel TJ, Marchak MA, PeruimboomBrees I, Brees DJ. Cardiac troponin I is a sensitive, specific biomarker of cardiac injury in laboratory animals. Lab Anim 2006;40:153-71.

49. Bertinchant JP, Robert E, Polge A, MartyDouble C, Fabbro-Peray P, Poirey S. Comparison of the diagnostic value of cardiac troponin I and $\mathrm{T}$ determinations for detecting early myocardial damage and the relationship with histological findings after isoprenaline-induced cardiac injury in rats. Clin Chem Acta 2000;289:13-28

50. McCauley PT, Washington JS. Barium bioavailability as the chloride sulfate, or carbonate salt in the rat. Drug Chem Toxicol 1983;6 Suppl 2:209-17.

51. Siwik DA, Chang DL, Colucci WS. Interleukin-1 $\beta$ and tumor necrosis factor- $\alpha$ decrease collagen synthesis and increase matrix metalloproteinase activity in cardiac fibroblasts in vitro. Circ Res 2000;86:1259-5

52. Liu P, Sun M, Sader S. Matrix metalloproteinases in cardiovascular disease. Can J Cardiol 2006; 22Suppl B:25-30.

53. EL-Deeb ME, Abd-EL-Hafez AA. Can Vitamin $\mathrm{C}$ affect the $\mathrm{KBrO} 3$ induced oxidative stress on left ventricular myocardium of adult male albino rats? A histological and immunohistochemical study. J Microsc Ultrastruct 2015;3:120-6.

54. El Boghdady NA. Antioxidant and antiapoptotic effect of proanthocyanidin and ginkobiloba extract against doxorubicin-induced cardiac injury in rats. Cell Biochem Funct 2013;31:344-1.

55. Klebanoff SJ. Myeloperoxidase: Friend and foe. J Leukoc Biol 2005; 77:598-25

56. Suzuki M, Mori M, Miura S. Omeprazole attenuates oxygenderived free radical production from human neutrophils. Free Radic Biol Med 1996;21:727-1.

57. Reyes A, Galindo MM, Garcia L. Ouabaininsensitive, Nap-stimulated ATPase of several rat tissues: Activity during a $24 \mathrm{~h}$ period. Physiol Res 2009;58:693-9. 